Insight

\title{
Agency and Resilience: Teachings of Pikangikum First Nation Elders, Northwestern Ontario
}

\author{
$\underline{\text { Andrew M. Miller }}^{1}$ and Iain Davidson-Hunt ${ }^{2,3}$
}

\begin{abstract}
Although scholars of social-ecological resilience propose unity between humans and the natural world, much of this work remains based on Cartesian division of mind and body that denies it. We present an example of a unified system of resilience thinking shared with us by Anishinaabe (Ojibway) elders of Pikangikum First Nation, northwestern Ontario. The elders' views of boreal forest disturbance and renewal are distinct from western scientific approaches in their recognition of agency, the ability to individually express free will in nonhuman beings including animals, plants, rocks, and forest fire within their landscape. Pikangikum elders perceive that, if relationships based on respect, reciprocity, and noninterference are maintained with other agents, renewal will continue. The proposition of living landscapes composed of diverse nonhuman agents poses challenges to collaboration with western worldviews, which view nature largely as mechanistic and without moral standing. We suggest that a greater attention to nonwestern ontologies can contribute to productive cross-cultural partnerships directed toward fostering resilience.
\end{abstract}

Key Words: agency; Anishinaabe; other-than-human persons; Pikangikum First Nation; resilience; social-ecological system

\section{INTRODUCTION}

Social scientists have noted the critical importance of agency, "the capacity of individuals and corporate actors with the diverse cultural meanings that they espouse, to play an independent causal role in history" (McLaughlin and Dietz 2008:105) in adaptive capacity, sustainability, vulnerability, and resilience (Brown and Westaway 2011). Within the western scientific tradition the distinction between "nature" and "culture" is the dominant paradigm by which the world is understood and acted upon (Davidson-Hunt and Berkes 2003a). Despite great strides made by social-ecological systems thinking toward unifying fields of "nature" and "culture," many works continue to be based upon a humancentric framework in which only human beings are considered as active in determining the course of future events through their exclusive possession of agency.

Although dating to pre-Aristotelian philosophy, the identification of consciousness as the cleavage between nature and culture is most often attributed to 17 th century French philosopher, René Descartes (1596-1650). The Cartesian "mind-body problem" posits that while the material (body) is subject to the laws of physics, mind (consciousness) largely exists independently from the physical world (Young 1990). Through this framing, humans alone are capable of perceiving time, acting with self-interest against future conditions, and communicating complex concepts through symbolic means, e.g., words (Westley et al. 2002). It follows that the ability to manipulate complex ecological systems to achieve desired outcomes is reserved for humans who are the sole possessors of consciousness. Conventional resource models assume that outcomes of management will be predictable in so far as management interventions are based upon accurate models of the systems they describe.

Comanagement has emerged as a paradigm to share responsibilities and benefits for resource management and to avoid the pitfalls of top-down management. In contexts involving indigenous peoples and state managers, comanagement has been criticized because of power imbalances originating from colonial histories that favor western over indigenous methods of knowledge creation, maintenance, and use (McGregor 2000, Nadasday 2005, Spak 2005, Houde 2007). More recently, examination of the conditions that allow comanagement to incorporate learning, evolution, and change to cope with uncertainty in social and ecological settings has arisen as adaptive comanagement (Armitage et al. 2007). Pluralism in the generation and sharing of knowledge has been recognized as among the keys to more appropriate, efficient, and equitable governance of resource management involving local and larger scale actors (Armitage et al. 2007, 2009). Doubleday (2007) points out that the ability to express one's cultural expectations, maintain institutions, and apply learning within these contexts in adaptive comanagement arrangements are measures of adaptive capacity within the system. Exploring the causes of disturbance and renewal and how they are best navigated to achieve social, cultural, and ecological goals is to venture into culturally specific fields of understanding. If we wish to integrate indigenous and nonindigenous knowledge systems to meet shared goals without falling prey to the asymmetries of power inherent between indigenous and colonial knowledge systems, than a more conscious effort must be made to understand indigenous peoples' notions of resilience. 
We present what we have learned from our indigenous Anishinaabe (Ojibway) colleagues of Pikangikum First Nation Ontario, Canada about their views of renewal processes as involving the many beings who potentially exhibit agency and thus play active roles in adaptive renewal processes. In contrast to Descartes's framework, which identifies humans as "agents" and everything else as "objects," Pikangikum elders recognize their landscape as a social space in which humans can only influence the outcomes of adaptive renewal through attentiveness to relationships with nonhuman being agents who will hold them accountable for their actions. Given an emergent interest in the resilience literature regarding agency and networks (Crona and Hubacek 2010, Brown and Westaway 2011, Coulthard 2012), we illustrate the potential for nonwestern cultures to provide alternative views of resilience, which stem from their beliefs of how the world is composed and functions.

Resilience literature published in Ecology and Society and in other journals has done much to reunite nature and culture as evidenced by the increased use of social-ecological systems (SES) as the appropriate conceptual framework for the management of natural resources. SES emerged as a conceptual framework through the two volumes edited by Berkes, Folke, and Colding (1998) and Berkes, Colding, and Folke (2003). In the 1998 volume, the link between social and ecological systems was presented as patterns of interactions among ecosystems, people, technology, local knowledge, and property rights that could lead to outcomes for a sustainable society (Berkes et al. 1998). Within the 2003 volume, the concept of social-ecological systems had emerged linking local ecosystems to management practices in which knowledge facilitates the bridging of cultural and natural realms (Berkes et al. 2003). Concurrently, other authors (Abel 1998, Abel and Stepp 2003) recognized that the new ecology at the core of resilience thinking offered possibilities for the social sciences, but were more comfortable with the idea of "human ecosystems" than social-ecological systems. By 2003 many authors had adopted social-ecological systems as a category of analysis that could evolve (Folke 2006, McAllister et al. 2006) and be compared (Abel et al. 2006); SES had become an accepted part of our scholarly lexicon.

However, this does not resolve the other legacy we inherited from Descartes as external observers of social-ecological systems, better known as the mind-body problem mentioned earlier. Those trained in the western scientific tradition tend to model the world in terms of collections of things that surround them rather than seeing a diversity of beings with whom relationships are possible. We have not, to use a popular metaphor, been able to pass through the looking glass into Wonderland (Carroll 1970) where others, be they human or nonhuman, may be actively engaged in their own dramas rather than just witnesses or props in ours. Understanding and collaborating with peoples who occupy a world in which human beings and nonhumans are morally equivalent and not divided into separate orders of being has been problematic (Natcher et al. 2007).

Gregory Bateson $(1973,1979)$ long ago recognized this as a necessary transformation to move from observers to actors within what we now call social-ecological systems. More recently, Tim Ingold (2000) and Bruno Latour (2005) have worked to resolve the nature/culture and mind/body dilemmas through their reconsideration of environmental perception and social interaction. These ideas have also been discussed in the resilience literature. Walker et al. (2002), for example, recognized that the framework of resilience they proposed "is probably limited by our western, developed-world optic on management." Later, Davidson-Hunt and Berkes (2003a:59) put forward the idea that we need to begin thinking about resilience from a "human-in-ecosystem" perspective, borrowing from the ideas Ingold (2000) had been developing regarding "dwelling" and the agency of actors as part of socialecological systems. Similarly, Abel and Stepp (2003) noted the importance of considering the role of human agency for human ecosystems. However, in none of these cases did the authors develop the implications of how nonhuman actors possessing agency might influence our thinking about resilience.

Given the "disenchantment" of science since the time of Descartes, academicians are not likely to find within modern western thinking guides for how to live as one among many (Davidson-Hunt 2006). We have often probed aboriginal peoples' knowledge about their environments, including how to reunite nature and culture in the resilience literature (Berkes et al. 2003). Elsewhere, we have begun to work with aboriginal elders, whom we consider natural history philosophers, to learn how to reimagine ourselves as members of holistic environments, reconfigure our understanding of the world in which we live, and how one comes to construct knowledge within it (Davidson-Hunt and Berkes 2003b, Davidson-Hunt et al. 2005, O'Flaherty et al. 2009, Shearer et al. 2009, Miller and Davidson-Hunt 2010). Being "non-modern" (sensu Latour 1993) and heirs to neither Greek nor Enlightenment philosophies provides indigenous peoples with not just instrumental knowledge but rich philosophies about the associations of human and nonhumans that allow for their survival (Dasmann 1988, Berkes et al. 1995, Colding et al 2003, Berkes and Turner 2006).

\section{Setting: Pikangikum First Nation}

Pikangikum First Nation is a remote Anishinaabe (Ojibwa) community in the boreal forest of northwestern Ontario, Canada. It is accessible by an ice road during the winter months, by boat and float plane during the months of open water or by small plane to the community airstrip. The boreal ecosystem is heavily influenced by periodic stand-replacing forest fires, which impact forest structure, stand creation and 
destruction, and species composition (Rowe and Scotter 1973, Weir et al. 2000). Many of the dominant species, e.g., jack pine (Pinus banksiana Lamb.), black spruce (Picea mariana Mill.), lodgepole pine (Pinus contorta Dougl.), and trembling aspen (Populus tremuloides Michx.) are fire dependent, requiring fire to open seed-bearing cones or to stimulate sprouting from below-ground roots (Rowe and Scotter 1973).

The official Pikangikum population estimate lists 2000 residents (Aboriginal Affairs and Northern Development Canada 2008), although local community population estimates approach 2400. Most residents speak their native Anishinaabe language as their first language (P. M. Ningewance, unpublished manuscript). Fishing, hunting moose (Alces alces) and waterfowl, trapping furbearers, and collecting berries (Vaccinium spp.) continue to make important contributions to the domestic economy. The forest, lake, and wetlands surrounding the community continue to be managed in a family trapline system established in the 1930s (Deutsch and Davidson-Hunt 2010). Although, many members of Pikangikum self-identify as evangelical Christians, they do not regard these beliefs as being in conflict with the distinctly indigenous beliefs and worldviews described in our research. This is especially true of the older generation. Elders in Anishinaabe culture are not just older people, but are highly esteemed individuals who have attained a respected status within their community by demonstrating traditional values, skills, and through their life experiences. They are cultural experts. Many of the elders participating in this project were also members of the Whitefeather Forest Elders Steering Group who initiated the forestry planning process and regularly provided oversight of the comanagement planning process that commenced in 1996 (Chapeskie et al. 2005).

The community of Pikangikum is surrounded by 1.3 million hectares of forested lands where they are currently undertaking collaborative forestry planning with the Ontario Ministry of Natural Resources (Pikangikum First Nation and OMNR 2006). This planning is taking place under the Northern Boreal Initiative, a Canadian program designed to give aboriginal communities greater influence on land use planning for their traditional territories.

\section{METHODS}

Our research is the product of a longstanding collaboration between Pikangikum First Nation and University of Manitoba researchers to support the elders' goals of cultural and economic development for the benefit of future generations (Pikangikum First Nation and OMNR 2006), procedures specified within the Whitefeather Forest Research Cooperative Agreement (Whitefeather Forest Initiative 2004). Our research began in 2006 during a community meeting when we presented to the elders our proposal to document Anishinaabe values associated with processes of forest fire, logging, and adaptive renewal cycles (Miller 2010). Elders approved and appointed several willing experts from among their number to describe their experiences with fire. It was ethnographic in that it included a long-term field stay by one of the authors and utilized multiple data collection procedures over the course of the research. Phenomenology informs our philosophical position because we are interested in the cultural construction of meaning related to specific environmental phenomena, in this case, dynamics related to ecological disturbance and renewal (Cresswell 2007). The research began with an extended period of participant observation during travels with participants on the land during hunting, trapping, and fishing expeditions. This period allowed for unstructured interviews related to the topics of ecological disturbance and renewal. As relationships with key participants were established, trips to the field were undertaken to visit disturbance and renewal sites, i.e., fire, blow downs, logging. We were accompanied during these trips by a translator. Interviews were recorded to create transcripts of discussions in the field to accompany field notes from this period. At the end of this phase all recordings were transcribed and both the transcriptions and field notes were coded utilizing key terms such as "disturbance," "fire," "soil," "regrowth," etc. We also allowed other concepts to emerge through grounded analysis and allowed for different ideas to emerge than originally considered in the research. This process then led to the emergence of key concepts in English and Anishinaabe. To check the validity of these concepts group verification sessions were held with elders in the Whitefeather office and were translated by the land-use coordinator. This was then followed by presenting these concepts to a meeting of the Elders Steering Committee and allowing for discussion in Anishinaabe that was translated by the land-use coordinator. Consistent with a phenomenological framing, the goal of these sessions was to find central concepts widely shared within the group rather than exploring who held which knowledge. The concept may be signified through the use of a word but such signifiers hold a complex set of philosophical propositions. Verification sessions allowed the group to discuss, debate, and modify the term that would be utilized and the set of propositions it contained. It is the results of this process that we report here in an effort to communicate central Anishinaabe concepts related to disturbance, renewal, and agency. In total 43 interviews were held and 30 elders participated in both the field trips and verification sessions.

\section{An ethnographic aside on agency}

It is important to recognize the work of ethnographers who have worked with Anishinaabeg (pl.) on the question of who exhibits agency. American ethnographer A. I. Hallowell (1892-1974) began his work with the peoples of the Berens River, including ancestors of modern Pikangikum residents, in the 1930s. Although his work occurred more than 75 years ago, the linguistic and cognitive orientations he described are 
now considered classics in the field of symbolic anthropology. Hallowell coined the term "other-than-human persons" to describe beings with whom a human could maintain "social relations" (Hallowell 1960:23). As Mary Black (1977a,b), another ethnographer who worked on this question with the Anishinaabe, suggests these include large and small mammals, insects, birds, fish, some plants, culture heroes, male and female thunderbirds, the sun, winds, stars, some lakes, and other forest spirits (Black 1977b). To realize the universal goal of living a "life in the fullest sense, life in the sense of longevity, health and freedom from misfortune" (Hallowell 1960:45), it was necessary to maintain good relations with both human and other-than-human beings.

Within Anishinaabe culture, the power, or agency, that beings possess and how they exercise it is influenced by adherence to the Anishinaabe norms and values related to reciprocity and appropriate behaviors in pursuing the necessities for one's own survival (Black 1977b, Davidson-Hunt and Berkes 2003b, Shearer et al. 2009). Within this worldview many beings with whom one interacts have the potential to be powerful agents who can assume the form of humans or other animals, and through such actions influence one's own life course for both good and bad. As Black (1977b:145) notes, "Interference with the self-determination of any of the 'living things' may have unpleasant consequences and is to be avoided. Among nonhumans, power-control is unevenly distributed, but all living things have some, and one can never know for certain."

A fundamental ontological proposition of all societies is the definition of who is accorded agency and as a result the existence of domains such as social, ecological, or spiritual to which a being may by assigned. In the case of the Anishinaabe, domains are not structured by agency because all beings have the potential of agency. Rather domains are organized by the particular form through which agency expresses itself such as corporeal and noncorporeal forms. For the Anishinaabe, then, there is one system of relations that must be navigated as opposed to two domains that must be articulated, such as social-ecological. The possession of life, i.e., agency, power, or creativity, as expressed through Pikangikum teachings is something that allows beings to grow, mature, develop, change physical form, and inhabit other physical forms and allows beings to influence their own and others' pursuit of a good life (Hallowell 1960, see Ingold 2000, Nadasdy 2007 for other subarctic examples). This attitude contributes to resolving the existential human paradox that sustaining life requires taking life (Martin 1982, Overholt and Callicott 1982). Many Anishinaabe, have yet to accept the western solution to this paradox through the disenchantment of the world and reservation of agency only for humans, with one set of social norms and behaviors for interacting with other humans and another set of ecological norms for interacting with nonhuman organisms and physical structures, i.e., plants, rocks, lakes.

\section{RESULTS}

This research began with an interest in understanding fire as a critical process of boreal adaptive-renewal cycles within the conceptual framework of resilience (Miller 2010, Miller and Davidson-Hunt 2010, Miller et al. 2010). Although unanticipated, what became apparent was that we also had to learn about agency before we could begin to comprehend what the elders wanted to teach about how they understand the dynamics of adaptive-renewal cycles.

It should be noted that when discussing the "environment" with Pikangikum elders we frequently resorted to terms such as "the land" (auhkee) to refer to the sum of life forms, including Pikangikum residents, and the relationships that exist between them (Pikangikum First Nation and OMNR 2006). This term, however, is also used to refer to smaller scales, describing small plants, mosses, and the soil directly beneath them. There is also a lack of equivalent terms in Anishinaabe for English terms such as "nature," "environment," or "ecosystems." Many indigenous peoples have a blurred boundary between what nonindigenous people consider territory and what they consider their own person. Expressions of the perceived linkages between the health of specific territories and the people who claim to have originated there are common (Booth 2003, Surrallés and Garcia Hierro 2005).

Many beings that are not considered to have agency by westerners have what the Pikangikum elders refer to as auyuhshawuhtun and what our translator often glossed as "life." Auyuhshawuhtun is something a being possesses, not a class into which beings can be classified, i.e., alive or dead, and its possession is dependent upon context and interactions with others rather than upon taxonomy or other classification (Davidson-Hunt et al. 2005). The range of forms that Pikangikum elders noted as possessing life included trees, animals, birds, standing dead trees, waters, wind, some rocks, and forest fire. What is important is not that there are classes of beings who can possess life and others who do not, but that all forms have the potential of agency and the source of life is the Creator and the natural order of that creation. A living landscape is infused with a life force and the range of agents is diverse.

All things have life. A stick - white people would describe it as dead, a piece of wood. ..Sand; water, all have life which I call auhyuhshuhwuhtuhn. Everything is alive because everything is connected to the Creator. Even the dead tree across the road is alive... See that hydro pole across the road? That also has auhyuhshuhwuhtuhn. It was once a tree and was taken off the land and made for this purpose into the pole. One day, maybe it will be replaced when it is too old and maybe it will be put to some other use-maybe fire wood. That will turn the pole 
into ashes that will go back onto the land to reenter the cycle. Another example is the leaves that grow on the trees during the summer. When they fall off in the fall they go to the ground and reenter the cycle by sustaining the auhkee. I don't believe the theory that leaves die. (Elder Mathew Strang, 1 March, 2007).

Elders observed that forest fire is in a constant state of change and motion and also possesses auyuhshawuhtun. They noted that, each time it burns, fire transforms its environment and the fuels it burns in ways that are somewhat predictable, yet ultimately unique. Many characteristics of forest fires were noted to be similar to those of a living creature including resting at night and resuming activity during the day, even creating new fires through transporting itself as embers across great distances. Forest fire can generate its own weather system consisting of in-drawn winds and large thunderhead clouds that contain lightning. As one elder stated, "Only the fire knows when it will stop" (Miller and Davidson-Hunt 2010).

Pikangikum elders recognize many societies with whom they share the land that they occupy. Examples of these are moose, beaver (Castor canadensis), jack pine, pin cherry (Prunus pensylvanica), sturgeon (Acipenser fulvescens), whitefish, duck, and eagle societies, among many others. Elders interviewed pointed out that all of the members of these societies are part of creation and have the potential to express agency to aid or hinder one's own agency, and that in interacting with these others, it is necessary to follow Anishinaabe teachings that include appropriate ways to relate and maintain reciprocity. These teachings were reflected in elders' careful consideration of when and how they refer to other beings. This consideration was in evidence during hunting trips; when in the bush, observing animal trails, an elder might say "someone has passed this way" rather than "something has passed." The use of a pronoun generally reserved for humans indicates that the elders' perceive their relationship to animals as being on a person-to-person level, rather than as a person-to-object.

Elders have observed that other beings demonstrate agency and express their own teachings in how they interact with others. This idea was made evident by Elder Whitehead Moose in his description of the impacts of forest fires, caused by powerful beings known as Thunderbirds (beenaysee) who reside in thunderclouds, create nests on land, and are responsible for some forest fires:

The Creator has a match and that match is the Thunderbird. He brings that match to the land when the forest gets too old and can't grow anymore. So the Thunderbird comes to earth. After the forest is burnt new growth starts. Animals get tired of eating old food. Just like you and me. The Creator knows that animals need new food. The fire there brings fresh food to eat. As an example: rabbit [sic: snowshoe hare] favors new growth area. When you look at rabbit I think it is like a food chain for animals. Rabbits have three litters a summer. Fox, lynx, marten all depend on rabbit. The Creator has to care for all animals so he sends Thunderbird to earth to make food for rabbit. We like to eat rabbit too. So He burns for us too. (Community meeting, 10 June, 2006)

This quote expresses a number of Anishinaabe teachings about the connectedness of humans and other beings. The Creator and the Thunderbird care for all beings on the land and, as we phrased it earlier, humans are only one among many beings. Animals exhibit preferences for certain kinds of food and get tired of others. Thunderbirds are like humans in that they are part of the natural order and must follow laws given to them by the Creator in their interactions with other beings and in doing so respect the agency of others. We might summarize this fundamental proposition of Anishinaabe ontology in the following way: The Creator is the source of life that is emergent from creation and can be possessed by many forms with whom humans interact over their life course. In the teachings of the Anishinaabe there is no moral distinction made in how you treat other humans in comparison to nonhumans because all are part of a social order and must be interacted with through the framework of moral values.

Although Pikangikum elders acknowledged that power may be differentially distributed among beings they pointed out that this does not create an ethical hierarchy that privileges one set of beings, e.g., humans, over another. None can be denied the right to exist or to be treated casually. All beings were seen to have their place within the community of beings, even those that might seem pernicious, such as mosquitoes or wasps. Complaints about the number of mosquitoes once prompted Elder Solomon Turtle (Interview, 1 September, 2006) to relate a story in which the mosquito (sahgeemay) once saved human beings from a Thunderbird who asked mosquito where it had found such good blood to drink. The mosquito responded that the blood came from a dead tree. To this day Thunderbirds strike dead trees looking for blood but do not strike human beings. Mr. Turtle concluded his story with a smile and shrug: "Mosquitoes have to eat too."

An important observation of elders' philosophy is that life is not lived in linear progression of time but rather is a series of interconnected cycles through which one forges a life path as days and seasons change, as one grows, matures, and develops and that can be marked by ceremonies (Davidson-Hunt and Berkes 2003b, 2010). The Pikangikum word gahgeesheebashkahmeegaak, has been translated as "something that keeps going around." It refers to the idea of cyclic changes such as the yearly cycle of seasons, the return of migrant birds, and changes in animal abundance. For animals this cycle consists 
of two processes: angook, "animals becoming scarce" and patenook, "animals becoming abundant." These cycles occur at seasonal scales as well as being linked to changes in habitat over many years (Miller and Davidson-Hunt 2010). Elders have described cycles for many animals including beaver, snowshoe hare (Lepus americanus), pileated woodpecker (maymay, Dryocopus pileatus), moose, marten (wabishayshee, Martes Americana) and woodland caribou (Rangifer tarandus caribou; A. M. Miller, unpublished data).

\section{The Creator's Plan: connectedness in a world of agents}

Beings that are alive and/or possess agency, i.e., auyuhshawuhtun, must be treated respectfully following the governing principles that the elders refer to as the Creator's Plan (Keechee manidoo oohnuhcheekayween). As cultural outsiders we admit that our understanding of the Creator's Plan is only partial. However, our work with Pikangikum elders has led us to understand several features that contribute to how life emerges from the connectedness of beings and processes that we suggest are parallel to ideas of resilience and adaptive renewal. These can be summarized as follows: (1) well-being: all beings are intended by the Creator to live well and may take what they need to live well; (2) noninterference: all beings have a purpose and it is wrong to interfere with that purpose; and (3) reciprocity: all beings must maintain reciprocal relationships with other community members; selfishness is viewed poorly.

Animals live out their lives in accordance with the Creator's Plan and their own understandings of how to live a good life. Animals themselves are understood as individuals who may express different preferences and behaviors within their own surroundings. Our research revealed that elders are uncomfortable being asked to characterize generalized behavior for "all moose" or "all caribou."

Everything on the land, plants and animals has a mind. Maybe you call it instinct. Fish have that too. Many times we think that animals are just animals. That's not true. They know where to find things to eat. They think. (Oliver Hill, 20 July, 2006).

Instead a person becomes an expert hunter in part through their accumulation of knowledge of the animals within the hunter's territory in relation to a landscape of potential resources, i.e., forage, water, cover, etc., and habitats, i.e., trails, shorelines, swamps, etc., that an animal may use. As such, reporting what an animal does is not equivalent to reporting the thinking which motivates its action.

I don't know what is going on in Iain's mind, so we have to think of the caribou in that way. I have seen scientists put collars on animals to track their movements but we don't actually know why they are moving about. (Oliver Hill, 15 December 2006, as cited in O'Flaherty et al. 2007).
Elders are very cautious about claiming to understand the motivations of other beings that can be seen as inherently disrespectful (Davidson-Hunt and Berkes 2003b, Natcher et al. 2007, O'Flaherty et al. 2008). However, one can be cautious in inferring their actions that may consist of moving across the land, finding food, encountering mates, and raising families. Although some people are recognized as having knowledge of caribou because of their experience interacting with them in the bush as they move across the land, find food, and pursue mates, it is not proper for anyone to speak authoritatively about what caribou need or what they are thinking; only caribou know that (O'Flaherty et al. 2007).

\begin{abstract}
The caribou was given life to live on the land by the Creator; the Creator's Plan has been initiated. We cannot give the caribou what they want to eat, we cannot tell the caribou where to live, only the Creator can do this. Even though we create boundaries on maps, we create all kinds of maps and boundaries, saying where the caribou are and where the caribou will eat, we don't know what the Creator's Plan is. (Charlie Peters, 1 March 2006).
\end{abstract}

The above quote has the additional implication that animals exist within networks of relationships including with the Creator just as human beings do.

Strong ethics of noninterference and self-determination have been noted by many social scientists working with Algonquin communities in realms of health care (Kelly and Minty 2007), cultural reproduction (Brant 1990), and education (Guilar and Charman 2009). Another cannot know what an individual needs until they communicate it. It is through the freedom to pursue one's life course as an individual and as a member of a society that a being can live well as the Creator intended. This ethic, as discussed earlier, is extended across the range of beings who are part of a diversity of societies with whom the Anishinaabe share the land.

One example of the consequences of not paying attention to the agency of other beings was presented to us by elders who visited a forestry operation to the south of Pikangikum. Boreal forests in this region are often managed using a clear-cut harvesting approach (pashkogaheegaywin), "cutting everything off the land." In many of these locations, reforestation occurs through the establishment of plantation forests of jack pines, the timber species with the highest future monetary return value. Prior to plantation establishment, harvest areas are cleared of slash and often scraped clear of deep organic soil so that jack pine seedlings can grow in underlying mineral soil. Slash and the organic humus layer are bulldozed off and disposed of by piling and burning (Fig. 1). Seedling trees are planted in rows as monoculture stands to maximize reestablishment of desired species and future return on investment while limiting tree competition and the need for future thinning treatments prior to harvest. According to 
Fig. 1. A timber harvest site adjoining the Whitefeather Forest Planning Area is "scarified," prepared for planting by scraping woody material and organic soils into piles for burning. This process exposes mineral soil for replanting of seedling trees and reduces hazardous fuel accumulations, but is seen by Pikangikum elders as disrespectful of the land and injurious to the healing processes. (Photo: N. Deutsch).

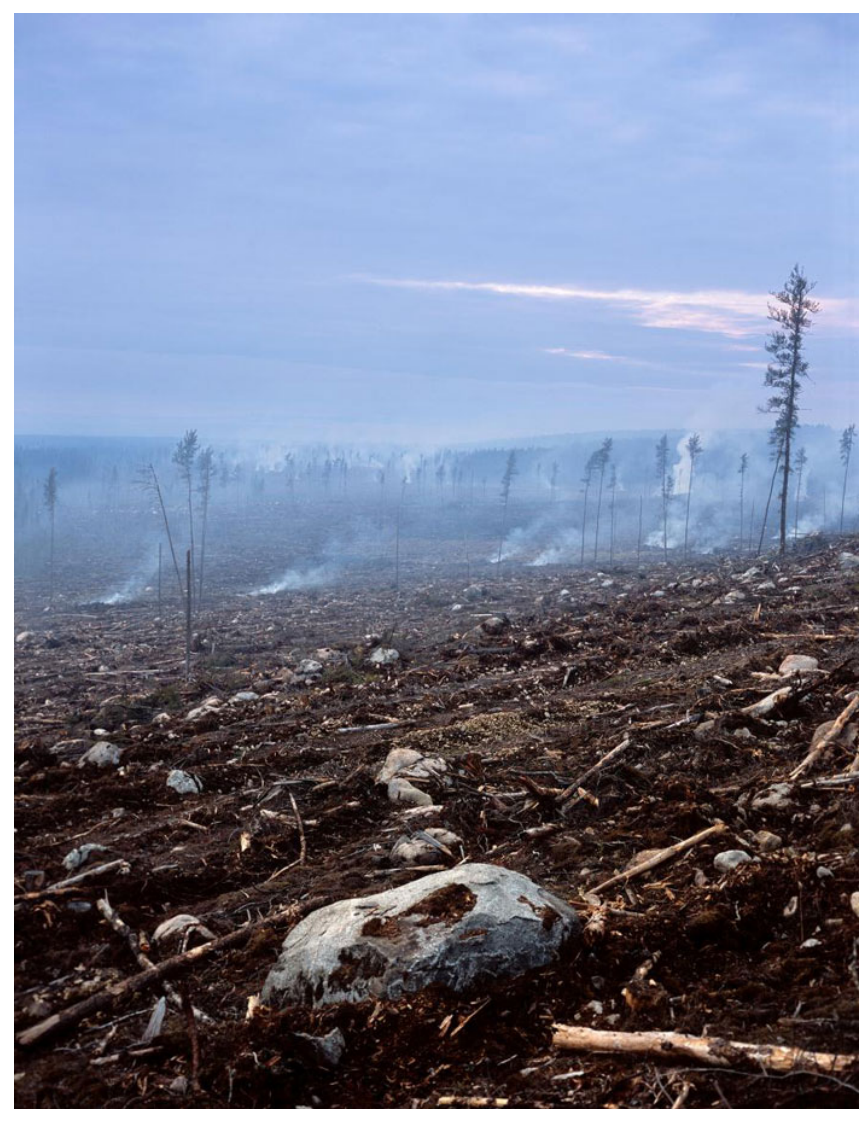

elders, when forestry operations attempt to create a forest following "man's own plan" the results are unhealthy. This in part due to dishonoring the land by forcing trees to grow where they would not normally grow. Elders state that disturbing rocks and soil in this way demonstrates a failure to show respect (cheepuhpeenootuhmun) and carries the potential for repercussions. Mixing of layers of black humus, sand, gravel, and clay within the soil is destruction of intentionally created order. Although elders are unable to say exactly what each of these layers contributes to the growth of specific plants, their presence is perceived as purposeful, and therefore destroying this organization within the soil is inappropriate.

In a clear-cut area, what the Whiteman is doing is breaking the ground... Everything is broken up and destroyed, the plants the roots, etc.... Clear-cutting actually wounds the auhkee severely. It is wounded to the point that that area will never be the same as it was originally. Rocks and stones have to be left in their proper place. Bulldozing after a clear-cut moves them all.... The teaching that I received when I was young was that it was wrong to go into the deep forest and disturb rocks and trees for no reason. (Mathew Strang, 1 March, 2007).

Poor outcomes in forest regeneration are seen as the result of interfering with the life course of trees that depend upon the roles played by fire, water, earth, and air. Many elders note that ash generated by forest fires is like fertilizer and creates rapid regrowth. By bulldozing off organic material and burning it separately, elders indicate that fertility is being wasted. This regrowth in combination with downed woody debris protects the soils from wind and water erosion. Ironically, elders describe the churned soil layers and torn earth of a clear cut as being burned in appearance (gahbeeday) for years after the harvest and site preparation occurs. This is manifest by bare soil and a shortage of small plants and mosses (also termed auhkee) that retain water, a clear sign of life. To demonstrate these differences more clearly, elders took us to observe a stand that was recovering from a forest fire (Fig. 2). They pointed out abundant plant life in the understory. Sapling poplar, black spruce, and jack pine were noted along with rabbit trails. As noted previously, rabbits are recognized as keystone species that assist the reestablishment of terrestrial fur bearer populations.

Fig. 2. Three years after a forest fire destroyed this mature forest there are many signs that Pikangikum elders recognize as ohneesheesheen (healthy; all things are as they should be) including regenerating blueberries, poplar, willow, and jack pine (Pinus banksiana Lamb.), important foods for game animals, and abundant moss and moisture. (Photo: A. M. Miller).

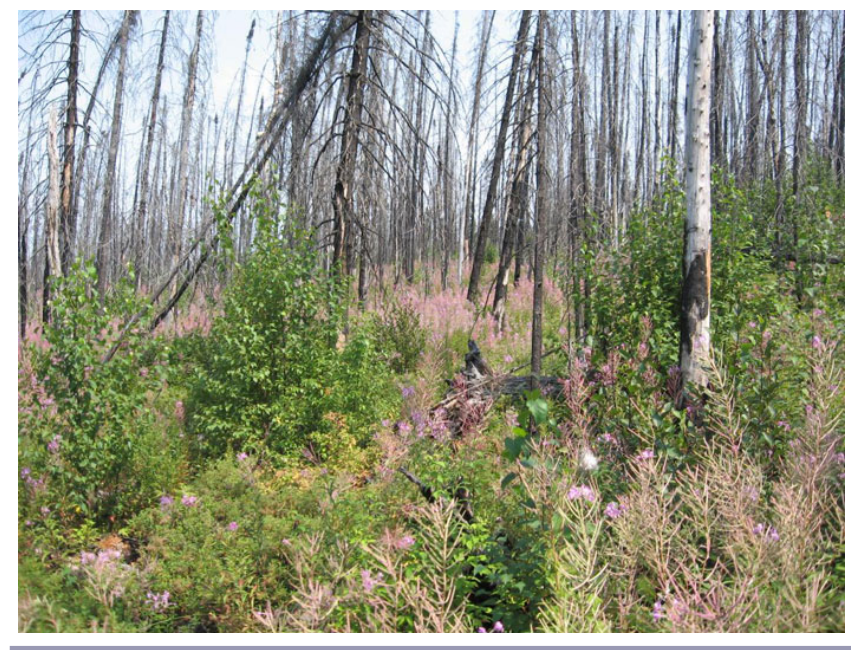


Table 1. Traditions that demonstrate respectful use and help maintain future abundance.

\begin{tabular}{ll}
\hline \hline Species & Respectful treatment contributing to renewal \\
\hline Moose (Alces alces) & The moose's beard is hung from a willow. \\
Beaver (Castor canadensis) & Guts and bones are returned to the lake. \\
Woodland caribou (Rangifer tarandus & Leave the guts and bones somewhere open where birds can get to it. The lake ice is \\
caribou) & kwaykwayshay's (Gray Jay, Perisoreus Canadensis) plate. \\
Grouse, duck, goose & A wing is hung from a willow. \\
Fish & Catch-and-release fishing is disrespectful. You take every fish you catch. \\
& Bones and guts are placed on shore or ice for gulls, eagles, or others. \\
\hline
\end{tabular}

In pursuing their own life-course hunters must exercise restraint by taking what is necessary for their own needs but not more than can be used. A very high value is placed on sharing with others especially those who are unable to harvest products of the land on their own such as elders as well as extended family and allies. Being able to share high quality resources from the land is a mark of pride and contributes to one's reputation as a good provider. However, to take more than one needs so that others are denied what they need to survive is viewed as lack of consideration, an infringement on the life of another who may offer their life for the survival as part of the Creator's Plan (Davidson-Hunt et al. 2005). Overuse disrespects the connections that plants and animals have with other beings that depend upon them for their own welfare. This disrespect may cause the plant or animal to withhold its gifts by failing to renew itself or precipitate unpredictable bad fortune for the offender.

Humans are responsible for demonstrating respect for the gifts offered to them by others. The Creator's Plan includes teachings that guide behaviors by which an Anishinaabe hunter can obtain what they need to survive. Respect is demonstrated by the performance of acts that show prey animals that the sacrifice of their life has been respectfully received (Table 1; Shearer et al. 2009). This may include symbolic acts that show the animal even in death that their gifts have been gratefully received. This may include hanging a part of the animal in a location near to its death or in a prominent place near camp (Fig. 3). Maintaining and following these customs contributes to the experienced abundance of what/who are needed for survival. For example, catching a fish requires knowledge and skill of where, when, and how to fish but it also requires appropriate moral behavior so that the fish will offer itself to the fisher. Through this lens practices like catch-and-release fishing are considered a rejection of the fish offering its life to the fisherman and may result in the fish withholding its gifts in the future. For Pikangikum residents, proper etiquette is to leave unwanted fish on the shore, on the ice, or on islands so that gulls, bald eagles (Haliaeetus leucocephalus), foxes (Vulpes vulpes), or other animals can make use of them. In this way, the lives of the fish have not been wasted but have gone to feed other
Fig. 3. Following a successful hunt Pikangikum hunters show respect to the animals that have given their lives by hanging a wing (Spruce Grouse, Falcipennis canadensis) or the "beard" of the moose (Alces alces). Doing so is believed to contribute to renewal of these animals. (Photo: A. M. Miller).

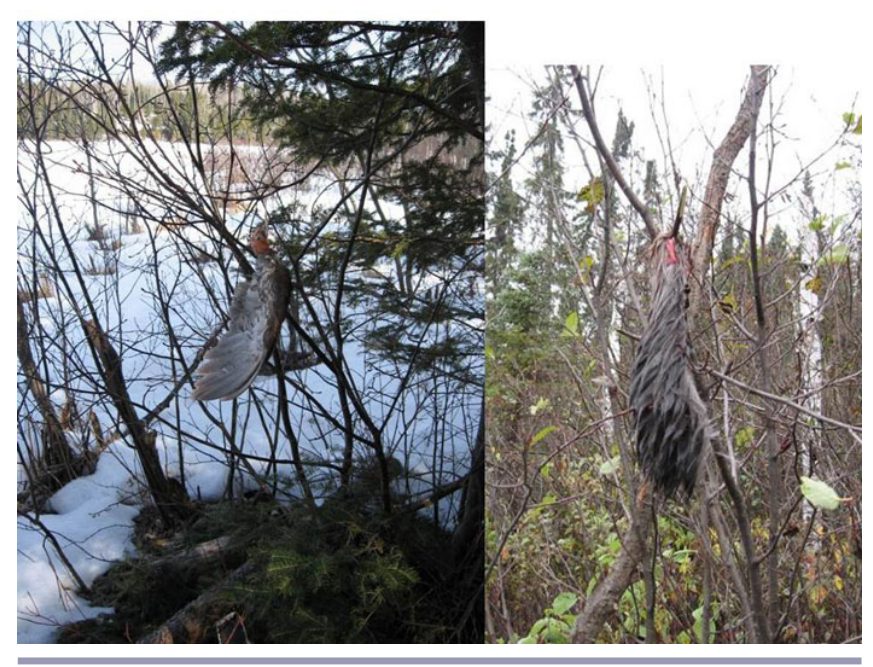

beings. What may be considered wasteful behavior in nonaboriginal cultural setting is profoundly appropriate by Pikangikum residents.

According to Whitehead Moose (Community meeting October 10, 2006) connectedness is achieved through the appropriate behavior in the receiving of gifts from others and maintains a reciprocity or balance (cheemeenooseg) and a good life. As an example, he cites his 25-year experience as a commercial fisherman on Moore Lake. During the first few years of fishing he caught many large pickerel (Sander vitreus) whose flesh was not good to eat. Through prolonged use, younger, more palatable individuals became more abundant. Whitehead suspected that, because there is no longer use of this lake, there are fewer fish than when he was using it. In this sense, failure to use resources can lead to diminished abundance. The elders say if the Creator's gifts are taken for 
granted they will be withdrawn. Others have expressed their belief that the lack of use has led to reduced abundance for woodland caribou (O'Flaherty et al. 2007), snowshoe hare, and beaver.

\section{Animals, stewards, and management}

According to Pikangikum elders, animals are capable of being stewards in the same way human beings are. The decisions of animals result either in maintenance of resources or in their degradation. For example, as previously noted, snowshoe hares are an important food to many predators including marten (Martes americana), fisher (Martes pennanti), lynx (Lynx canadensis), and fox. By taking snowshoe hares, predators ensure that there are more in the future. Failure to do so leads to declines in hare abundance when their unchecked population outstrips renewal of food resources. Equally, predators can reduce prey populations by being immoderate in their use. Elders perceive neither outcome as inevitable but instead are dependent on the decisions that individual predators make in relation to specific populations of snowshoe hares.

Pikangikum elders do not agree that "the ability to adopt forward-looking behavior is a definitive feature of human systems," nor that animals are incapable of giving or receiving abstract complex communication (Westley et al. 2002:116). Beaver (ahmik) and muskrat (waasheshk; Ondatra zibethicus) anticipate harsh weather by stockpiling more poplar limbs outside of lodges and larger vegetation mats to serve as winter food. Moose, birds, and other animals are believed to have their own ways of communicating with members of their own kind. As one elder pointed out, understanding the communications of animals requires no more practice than Anishinaabe people and Wahmedekooshe (White person) require to understand each other's ways of speaking. In Pikangikum, ravens (kaakaake; Corvus corax) and human hunters cooperatively hunt through communication between the raven and the hunter. A hunter pursuing moose keeps a watchful eye on the behavior of ravens. A barrel-roll in midflight by a raven indicates that it may be over a moose. Pikangikum hunter, John-Pierre Kejick said that a raven doing this is "taking off its big load" (ehpahgicheewahnej). "He helps you find a moose because he knows he will eat." We witnessed ravens perform this behavior twice during moose hunts; both times the barrel rolling raven was over a bedded or wounded moose (A. Miller, personal observation, February, 2007) and left offal from the butchered moose to thank the raven for helping us find it.

Elder Gideon Peters related a story told to him by his father about black bear (makwa; Ursus americanus) being able to start forest fires by lifting up rocks and slamming them down to produce sparks. "They do this because they know there will be berries there [following a fire] and it will get to eat. What do you think of that?" (Community meeting, March 6, 2007).
Humorously, other elders said they didn't think OMNR would believe Mr. Peter's story. They joked that OMNR believes in Smokey Bear, who wears pants and a hat and tells people to put out fire. Although they understand Smokey Bear is a fictitious character, they also clearly thought a bear who wouldn't understand the benefit of forest fire was ridiculous.

The elders perceive qualitative differences between the stewardship activities in which they wish to engage, and "management" as practiced by nonaboriginal forest operations to the south of their community. Their ideal form of resource and environmental stewardship is based on their desire to maintain Anishinaabe amahtahzeewin, 'an Anishinaabe way of life,' and is based on the Creator's Plan, principles of the respect, reciprocity, and noninterference that dictate how beings should interact to maintain balance, environmental health, and renewal.

For example, elders report that historically grassy marshes were burned in the spring time to clear away dead vegetation and provide a vigorous regrowth of grass (Miller and Davidson-Hunt 2010). These areas are reported to have provided good habitat for ducks and muskrats, important food for fur bearing animals, and grasses that were harvested in the fall for winter insulation. Frogs, blackbirds, and other animals were also more abundant in these areas. These traditional fires were seen as a form of stewardship that provided more food for others and in so doing, a better life for all. "We would burn wherever we saw that it would do some good" said Charlie Peters. As Elder Oliver Hill commented, "We have to respect these areas because we got a lot of food from them."

Elders commented that "management," as currently practiced following western approaches, is filled with acts that contradict their understandings of how their ecosystem works. All aspects of the Creator's Plan are ignored in western science-based forest management. It disrespects the soil by destroying intentional order and by removing erosion protection, interferes with the movements of water that denies trees the ability to choose where and how they grow. It presumes that beings such as animals and trees who possess agency and who, according to the Creator's Plan, must be allowed to act freely, can instead be controlled completely without repercussions. Elders recognize the agency of nonhumans undermines the effectiveness of "command and control" approaches to management in systems that are complex, demonstrate nonlinearity, and for which complete knowledge remains impossible (Holling and Meffe 1996).

\section{FINAL REFLECTIONS}

\section{Cross-cultural approaches to resilience}

We have presented a view of agency, resilience, and adaptive renewal processes shared with us by Pikangikum First Nation elders. Through attending to aspects of their worldview we 
also learned that resilience is inherent to living landscapes and the place of human beings as one agent among many (Davidson-Hunt 2006). Although rocks and forest fires do not have genetic material or carry out metabolic processes indicative of biologically defined "life" as nonaboriginal society recognizes it, these characteristics are not relevant to the way Pikangikum elders think about and act within a land imbued with agencies and a diversity of potential actors. Although we recognize that more focused work is needed on this concept, it is reminiscent of Cruikshank's (2001) multicultural discussion of glaciers; Pikangikum elders identify their boreal landscape as social space where they may be held accountable for lapses in behavior. By seeing the world as objects and groups of objects acting and reacting together, western science seeks to establish replicable causal relationships that are divorced from location and independent of observer (Cruikshank 2001). Cruikshank comments on the impact of Cartesian reasoning on indigenous landscapes: "Sentient landscapes shift their shape once they are engulfed by these frameworks and transformed into 'land and resources' " (Cruikshank 2001:389). This stands in contrast to the phenomenology employed by indigenous people in which located histories, experiences, and the roles of different actors are considered highly relevant to observed outcomes. By asking Pikangikum elders about disturbance and adaptive renewal cycles, we were required to learn how a living landscape contains life forces and how individual behavior has implications for the way life unfolds within a network of beings. A central proposition of Anishinaabe philosophy is that resilience emerges out of the ethical frameworks that guide how humans behave in relation to other agents. Other beings do not respond mechanistically but are perceived to express their agency in relation to whether reciprocity is maintained through gifting, respect is shown through proper behaviors, and interference with their pursuit of a good life by others is avoided unless required for survival.

The attribution of agency to nonhumans, maintenance of rules of reciprocity, respect, and noninterference are unique approaches to resolving the nature-culture divide of western philosophy and have contributed to the ability of the Anishinaabe people of Pikangikum to navigate cycles of adaptive renewal in an uncertain world. They represent a single possible solution among hundreds of indigenous communities and cultures in North America and the potential diversity of models for adaptive renewal in indigenous cultures the world over. An Anishinaabe worldview begins with the ontological proposition that there is only one world to be navigated through careful attention to relations with others. As we understand Pikangikum elders, life unfolds through cycles interacting with sets of relations with others that carry ethical and moral responsibilities. Such cycles are expected to follow known patterns and when they don't, can result in careful observation of others, introspection, and discussions with others to determine whose actions (be they human, animal, geological, etc.) contributed to the deviation (Davidson-Hunt and Berkes 2003b, Davidson-Hunt 2006). Introspection, in particular, would focus on transgressions related to moral and ethical behavior in relation to others. The consequences for breaking moral or ethical rules are unpredictable, potentially serious, and recognized as something to avoid whenever possible. In this sense, resilience inheres in the ability of Anishinaabe people as individuals and societies to navigate and mediate these sets of relations in what is seen to be a cyclical and uncertain world where the intentions and powers of agents are not fully knowable.

As noted previously, resilience literature has increasingly included discussions about agency and resilience as it has tried to bring together systems and agent-centered approaches (Coulthard 2012). In this discussion to date, however, there has been little discussion of the worldviews of indigenous communities regarding agency, adaptive-renewal cycles, and resilience. However, worldviews have been recognized as a key component of traditional ecological knowledge (Houde 2007, Berkes 2012), providing members of a specific culture unique sets of views on how the world is constituted, how it functions, and what actions will permit a person to achieve a meaningful, moral, and successful life. Worldview is increasingly relevant as agency is brought into discussions of resilience and well-being (Brown and Westaway 2011, Coulthard 2012) with particular importance in reference to indigenous societies.

Adaptive comanagement has postulated that a necessary condition for successful comanagement is the creation of forums of cross-cultural learning and the inclusion of a "plurality of knowledge systems and sources" (Armitage et al. 2009:101). An in-depth discussion of the pros and cons of incorporating indigenous views of resilience into planning documents and resulting management outcomes is beyond the scope of this paper. However, our participation in and observation of comanagement planning does provide us several insights. First, it is difficult to overstate the importance of providing space within comanagement documents for expressions of indigenous ontologies. Including concepts of resilience that make sense within the local vernacular in planning and management documents may allow communities to more easily create consensus and mobilize for collective action. One notable example in our case study was the elders' desire to identify the Creator (Keechee manidoo) as the source of the authority of Pikangikum people to manage the land. In their view, their authority stemmed from the Creator who had placed them upon the land of the Whitefeather Forest Area (Pikangikum First Nation and OMNR 2006). Although Ontario forestry planners initially resisted inclusion of this statement, elders steadfastly refused to remove the centrality of the Creator within their plan. As one community observer reported, the issue could have been a deal breaker for many 
participating elders and led to their withdrawal of their support for the planning process. By including an acknowledgement of the Creator, elders are expressing their view that modern forestry is an extension of existing spiritual relationships between the people of Pikangikum and the land community under the guidance of the Creator. Land use planning documents thus became a positive cultural expression affirming the people of Pikangikum's place in the world as legitimate participants in creating their own future within their territory on their own terms.

As one of our reviewers commented, this overt recognition of the Creator's importance also allows representation of spiritual or sacred dimensions within the purview of resource management, a dimension which is often diminished or entirely absent from planning. Although the importance of spirituality has been common in the literature regarding indigenous science and traditional ecological knowledge (Cajete 1999, Berkes 2012), it has also been recently recognized as an important area of investigation regarding the relationship between worldviews and sustainability in diverse societies (Hedlund-de Witt 2012). However, this is still an unfolding conversation between Aboriginal society and Canadian resource management agencies.

Although it is easy to call for understanding among worldviews, putting that into practice within existing management practice and institutions can be challenging. Are we in fact willing to return to our previous metaphor, to pass through the looking glass into Wonderland, in an effort to maintain respectful relations with partners who have yet to reconcile the division of the world into social and natural realms? As one collaborating participant in forestry planning from the Ontario Ministry of Natural Resources commented, "When the elders talk about understanding animals to be individuals and management as incorrect ... I understand and support what they are saying. I just go back to my desk and I don't know what to do with it" (C. Cuthbertson, Summary Meeting February 18, 2008).

As an individual Mr. Cuthbertson was willing to listen and try to understand Anishinaabe perspectives on forest management but was also aware that he was limited by the legislation that guides his actions and decisions. The OMNR is legally mandated to provide access to natural resources for economic development while protecting resources and other natural values for current and future generations and responding to the best available science and local, provincial, federal, and international political and financial realities. At the local level, there has been receptivity to the ideas communicated in this paper. However, as an earlier review of this paper demonstrated the attribution of agency to nonhumans weakens the differentiation between social and ecological domains, challenges both social and ecological sciences and natural resource management policy built upon those foundations.
Unless the space is created within legislation and policy to allow local values and knowledge such as those embodied in traditional knowledge to be utilized, what is learned at the local level among resource managers will be constrained by dominant processes of knowledge production and management.

Including indigenous ontologies in comanagement planning requires a great deal of time, money, level of commitment, and patience. The Whitefeather Forest Management Plan has been underway since 1996 (Chapeskie et al. 2005). It has required the participation of multiple branches of Canadian provincial and federal government. Fortunately, a consistent level of funding for the planning has been available to support the continuity of ministry participants and elders who must take time from their other duties and families to attend meetings. Over the years elders have had to patiently educate newcomers to the Anishinaabe worldview. Although the vision and sensitivity of ministry personnel has been extraordinary, from time to time misunderstandings have occurred. In one instance a ministry forester proposed prescribed fires as a natural fit for the community given traditional burning practices (Miller and Davidson-Hunt 2010) and as a legitimate "tool in the management toolbox." One elder responded that it is not right to regard fire, a living thing with agency, as a tool: "A hammer is a tool. I can take a hammer out of a tool box and I use it. Fire is not a tool like a hammer that I can take and use. You can't talk about fire this way." The implied relationship between human agents and fire, which the forester believed could not express agency and thus be controlled, resulted in confusion and consternation on the part of Pikangikum elders. The elder's objection underscored the lack of control that managers ultimately possess over weather, fuels, and other variables that can affect the outcomes of using fire in management situations. Although elders and forest managers expressed their appreciation of each other's knowledge of forest processes, communication and cooperation in this instance was impeded by disagreement on the potential for agency of a nonhuman being. The position elders have taken is one that requires that relationships with the beings within their landscape be maintained. Relationships are implicitly subjective, depending on the agency of human participants and other beings. As a comment by one reviewer alerts us, subjective relations may be difficult for some believers in objective reality such as scientists and managers to achieve or support. The costs in efficiency are not known to us at this time. We propose this as an opportunity for expanding knowledge coproduction between indigenous and nonindigenous land managers.

Like many indigenous peoples, Pikangikum elders seek cultural and economic revitalization. The two goals are in fact envisioned by the elders to be linked, with increasing employment in the forestry sector being seen as a means to reengage community members with the deeply meaningful 
cultural landscape (Davidson-Hunt et al. 2012). We do not anticipate that elders' knowledge and worldviews referred to here are identical to younger generations. Their statements may be interpreted as teachings for the present and future generations. This was in fact the manner in which our interviews began, as a request for their teachings. We do not know the future relationship Pikangikum people will develop in relation to these beliefs as their interactions with global economies and worldviews increase. In summer 2012 OMNR approved the forest management plan authored by forestry consultants under the direction of the Elders Steering Group and the Pikangikum land use strategy (Pikangikum First Nation and OMNR 2006). The continued success of Pikangikum First Nation is a sign that the Anishinaabe ethics toward nonhuman beings like those we describe, may not be incommensurable with more mainstream approaches to forest management. Although it is too early to know how this Anishinaabe approach to resilience may impact forestry practice and sustainability it would be worth allowing people with different ontologies to forge new pathways for resource management rather than interfering with their ability to pursue a good life (Berkes and Folke 1998).

Responses to this article can be read online at: http://www.ecologyandsociety.org/issues/responses. php/5665

\section{Acknowledgments:}

We owe thanks to the many elders of Pikangikum First Nation especially, the fondly remembered Elder Oliver Hill (Aug 1, 1938-Dec 18, 2011) for their generous participation in this research. We thank Pikangikum First Nation chief and council for their permission to conduct this research. Thanks to the members of the Whitefeather Forest Management Corporation, Alex Peters, Paddy Peters, Charlie Pascal, Reggie Peters, Murray Quill, Maureen Quill, Alec Suggashie, and Marcela Kejick. Funding for this research was gratefully received from the Sustainable Forest Management Network (Davidson-Hunt, PI), SSHRC (Davidson-Hunt, PI), Environment Canada Aboriginal Capacity Building Fund (WFMC), and University of Manitoba Graduate Fellowship (Miller). Publication was funded through the Clayton $H$. Riddell Endowment to the University of Manitoba's Faculty of Environment, Earth, and Resources. Comments were also graciously contributed by Shirley E. Bartz. We also recognize the anonymous reviewers of this paper and editors of Ecology and Society who helped us clearly communicate the central message of the paper. We also thank the anonymous reviewer who through their initial skepticism provided us with ongoing inspiration for the relevance of this work.

\section{LITERATURE CITED}

Abel, T. 1998. Complex adaptive systems, evolutionism, and ecology within anthropology: interdisciplinary research for understanding cultural and ecological dynamics. Journal of Ecological Anthropology 2:6-29. [online] URL: http://shell. cas.usf.edu/jea/PDFs/abel.pdf

Abel, N., D. H. M. Cumming, and J. M. Anderies. 2006. Collapse and reorganization in social-ecological systems: questions, some ideas, and policy implications. Ecology and Society 11(1): 17. [online]URL: http://www.ecologyandsociety. org/vol11/iss 1/art17/

Abel, T., and J. R. Stepp. 2003. A new ecosystems ecology for anthropology. Conservation Ecology 7(3): 12. [online] URL: http://www.consecol.org/vol7/iss3/art12

Aboriginal Affairs and Northern Development Canada. 2008. Pikangikum - First Nations profile. Aboriginal Affairs and Northern Development Canada, Gatineau, Québec, Canada. [online] URL: http://pse5-esd5.ainc-inac.gc.ca/FNP/Main/ Search/FNRegPopulation.aspx?BAND NUMBER=208\&lang= $\underline{\text { eng }}$

Armitage, D., F. Berkes, and N. Doubleday, editors. 2007. Adaptive co-management: collaborating, learning and multilevel governance. UBC Press, Vancouver, British Columbia, Canada.

Armitage, D. R., R. Plummer, F. Berkes, R. I. Arthur, A. T. Charles, I. J. Davidson-Hunt, A. P. Diduck, N. C. Doubleday, D. S. Johnson, M. Marschke, P. McConney, E. W. Pinkerton, and E. K. Wollenberg. 2009. Adaptive co-management for social-ecological complexity. Frontiers in Ecology and the Environment 7(2):95-102. http://dx.doi.org/10.1890/070089

Bateson, G. 1973. Steps toward an ecology of mind. Paladin, London, UK.

Bateson, G. 1979. Mind and nature. Dutton, New York, New York, USA.

Berkes, F. 2012. Sacred ecology. Third edition. Routledge, New York, New York, USA.

Berkes, F., J. Colding, and C. Folke. 2003. Introduction. Pages 1-29 in F. Berkes, J. Colding, and C. Folke, editors. Navigating social-ecological systems: building resilience for complexity and change. Cambridge University Press, Cambridge, UK.

Berkes, F., and C. Folke. 1998. Linking social and ecological systems for resilience and sustainability. Pages 1-25 in F. Berkes and C. Folke, editors. Linking social and ecological systems. Cambridge University Press, Cambridge, UK.

Berkes, F., C. Folke, and J. Colding. 1998. Linking social and ecological systems: management practices and social mechanisms for building resilience. Cambridge University Press, Cambridge, UK. 
Berkes, F., C. Folke, and M. Gadgil. 1995. Traditional ecological knowledge, biodiversity, resilience and sustainability. Pages 281-299 in C. A. Perrings, K.-G. Mäler, C. Folke, C. S. Holling, and B.-O. Jansson, editors. Biodiversity conservation. Kluwer, Dordrecht, The Netherlands. http://dx. doi.org/10.1007/978-94-011-0277-3 15

Berkes, F., and N. Turner. 2006. Knowledge, learning and the evolution of conservation practice in social-ecological system resilience. Human Ecology 34(4):479-494. http://dx.doi. org/10.1007/s10745-006-9008-2

Black, M. B. 1977a. Ojibway taxonomy and percept ambiguity. Ethos 5:90-118. http://dx.doi.org/10.1525/ eth.1977.5.1.02a00070

Black, M. B. 1977b. Ojibwa power and belief system. Pages 141-151 in R. D. Fogelson and R. N. Adams, editors. The anthropology of power: ethnographic studies from Asia, Oceania and the New World. Academic Press, New York, New York, USA.

Booth, A. L. 2003. We are the land: Native American views of nature. Pages 329-349 in H. Selin, editor. Nature across cultures: views of nature and the environment in non-western cultures. Kluwer, Dordrecht, The Netherlands. http://dx.doi. org/10.1007/978-94-017-0149-5_17

Brant, C. C. 1990. Native ethics and rules of behaviour. Canadian Journal of Psychiatry 35(6):534-539.

Brown, K., and E. Westaway. 2011. Agency, capacity, and resilience to environmental change: lessons from human development, well-being, and disasters. Annual Review of Environment and Resources 36:321-42. http://dx.doi. org/10.1146/annurev-environ-052610-092905

Cajete, G. 1999. Native science: natural laws of interdependence. Clear Light, Santa Fe, New Mexico, USA.

Carroll, L. (Rev. C. L. Dodgson). 1970. The annotated Alice. Penguin, London, UK.

Chapeskie, A. J., R. M. O'Flaherty, A. Peters, and N. Quill. 2005. The Whitefeather Forest Initiative: indigenous wisdom guiding a new community forestry opportunity in the boreal forest. Pages 7-37 in Sharing indigenous wisdom: an international dialogue on sustainable development. College of the Menominee Nation Press, Keshena, Wisconsin, USA.

Colding, J., T. Elmqvist, and P. Olsson. 2003. Living with disturbance: building resilience in social-ecological systems. Pages 163-186 in F. Berkes, J. Colding, and C. Folke, editors. Navigating social-ecological systems: building resilience for complexity and change. Cambridge University Press, Cambridge, UK. http://dx.doi.org/10.1017/CBO9780511541957.011

Coulthard, S. 2012. Can we be both resilient and well, and what choices do people have? Incorporating agency into the resilience debate from a fisheries perspective. Ecology and Society 17(1): 4. http://dx.doi.org/10.5751/ES-04483-170104

Creswell, J. W. 2007. Qualitative inquiry and research design: choosing from among five approaches. Second edition. Sage, Thousand Oaks, California, USA.

Crona, B., and K. Hubacek. 2010. The right connections: how do social networks lubricate the machinery of natural resource governance? Ecology and Society 15(4): 18. [online] URL: http://www.ecologyandsociety.org/vol15/iss4/art18/

Cruikshank, J. 2001. Glaciers and climate change: perspectives from oral tradition. Arctic 54(4):377-393.

Dasmann, R. F. 1988. Towards a biosphere consciousness. Pages 277-288 in D. Worster, editor. The ends of the Earth: perspectives on modern environmental history. Cambridge University Press, Cambridge, UK. http://dx.doi.org/10.1017/ CBO9781139173599.013

Davidson-Hunt, I. J. 2006. Adaptive learning networks: developing resource management knowledge through social learning forums. Human Ecology 34(4):593-614. http://dx. doi.org/10.1007/s10745-006-9009-1

Davidson-Hunt, I. J., and F. Berkes. 2003a. Nature and society through the lens of resilience: toward a human-in-ecosystem perspective. Pages 53-82 in F. Berkes, J. Colding, and C. Folke, editors. Navigating social-ecological systems: building resilience for complexity and change. Cambridge University Press, Cambridge, UK.

Davidson-Hunt, I. J., and F. Berkes. 2003b. Learning as you journey: Anishinaabe perception of social-ecological environments and adaptive learning. Conservation Ecology 8 (1): 5. [online] URL: http://www.consecol.org/vol8/iss1/art5/

Davidson-Hunt, I. J., and F. Berkes. 2010. Journeying and remembering: Anishinaabe landscape ethnoecology from northwestern Ontario. Pages 222-240 in L. Main Johnson and E. S. Hunn, editors. Landscape ethnoecology: concepts of biotic and physical space. Berghahn, New York, New York, USA.

Davidson-Hunt, I., N. Deutsch, and A. M. Miller. 2012. Pimachiowin Aki cultural landscape atlas: land that gives life. Pimachiowin Aki Coorporation, Winnipeg, Manitoba, Canada.

Davidson-Hunt, I. J., P. Jack, E. Mandamin, and B. Wapioke. 2005. Iskatewizaagegan (Shoal Lake) plant knowledge: an Anishinaabe (Ojibway) ethnobotany of northwestern Ontario. Journal of Ethnobiology 25(2):189-227. http://dx.doi. org/10.2993/0278-0771(2005)25[189:ISLPKA]2.0.CO:2

Doubleday, N. 2007. Culturing adaptive co-management: finding keys to resilience in asymmetries of power. Pages 
228-246 in D. Armitage, F. Berkes, and N. Doubleday, editors. Adaptive co-management: collaborating, learning and multilevel governance. UBC Press, Vancouver, British Columbia, Canada.

Duestch, N., and I. J. Davidson-Hunt. 2010. Pikangikum family hunting areas and traplines: the intersection of customary lands, planning areas and aboriginal land use planning in Ontario's far north. Sustainable Forest Management Network. CCI Press, Edmonton, Alberta, Canada.

Folke, C. 2006. Resilience: the emergence of a perspective for social-ecological systems analyses. Global Environmental Change 16:253-267. http://dx.doi.org/10.1016/j.

gloenvcha.2006.04.002

Guilar, J., and L. Charman. 2009. Saying what we mean; meaning what we say: authentic dialogue in aboriginal communities. Pages 187-202 in P. Vannini and J. P. Williams, editors. Authenticity in culture, self, and society. Ashgate, Farnham, UK.

Hallowell, A. I. 1960. Ojibwa ontology, behavior and world view. Pages 19-52 in S. Diamond, editor. Culture in history: essays in honor of Paul Radin. Columbia University Press, New York, New York, USA.

Hedlund-de Witt, A. 2012. Exploring worldviews and their relationships to sustainable lifestyles: towards a new conceptual methodological approach. Ecological Economics 84:74-83. http://dx.doi.org/10.1016/j.ecolecon.2012.09.009

Holling, C. S., and G. K. Meffe. 1995. Command and control and the pathology of natural resource management. Conservation Biology 10(2):328-337. http://dx.doi.org/10.1046/ j.1523-1739.1996.10020328.x

Houde, N. 2007. The six faces of traditional ecological knowledge: challenges and opportunities for Canadian comanagement arrangements. Ecology and Society 12(2): 34. [online] URL: http://www.ecologyandsociety.org/vol12/iss 2/ $\underline{\operatorname{art} 34}$

Ingold, T. 2000. The perception of the environment: essays in livelihood, dwelling and skill. Routledge, Longdon, UK.

Johnston, B. 1976. Ojibway heritage. University of Nebraska Press, Lincoln, Nebraska, USA.

Kelly, L., and A. Minty 2007. End-of-life issues for aboriginal patients. Canadian Family Physician 53(9):1459-1465.

Latour, B. 1993. We have never been modern. Translated by C. Porter. Harvard University Press, Cambridge, Massachusetts, USA.

Latour, B. 2005 Re-assembling the social: an introduction to actor-network-theory. Oxford University Press, New York, New York, USA
Martin, C. 1982. Keepers of the game: Indian-animal relationships and the fur trade. University of California Press, Berkeley, California, USA.

McAllister, R. R. J., N. Abel, C. J. Stokes, and I. J. Gordon. 2006. Australian pastoralists in time and space: the evolution of a complex adaptive system. Ecology and Society 11(2): 41. [online] URL: http://www.ecologyandsociety.org/vol11/iss2/ $\underline{\operatorname{art} 41 /}$

McGregor, D. 2000. The state of traditional ecological knowledge research in Canada: a critique of current theory and practice. Pages 436-458 in R. Laliberte, P. Settee, J. Waldram, R. Innes, B. Macdougall, L. McBain, and F. Barron, editors. Expressions in Canadian native studies. University of Saskatchewan Extension Press, Saskatoon, Saskatchewan, Canada.

McLaughlin, P., and T. Dietz. 2008. Structure, agency and environment: toward an integrated perspective on vulnerability. Global Environmental Change 18:99-111. http://dx.doi.org/10.1016/j.gloenvcha.2007.05.003

Miller, A. M. 2010. Living with boreal forest fire: Anishinaabe perspectives on disturbance and collaborative forestry planning, Pikangikum First Nation, northwestern Ontario. Dissertation, Natural Resources Institute, University of Manitoba, Winnipeg, Manitoba, Canada.

Miller, A. M., and I. J. Davidson-Hunt. 2010. Fire, agency and scale in the production of aboriginal cultural landscape. Human Ecology 38(3):401-414. http://dx.doi.org/10.1007/ $\underline{\text { s10745-010-9325-3 }}$

Miller, A. M., I. J. Davidson-Hunt, and P. Peters. 2010. Talking about fire: Pikangikum First Nation elders guiding fire management. Canadian Journal of Forest Research 40:2290-2301. http://dx.doi.org/10.1139/X10-177

Nadasdy, P. 2005. The anti-politics of TEK: the institutionalization of co-management discourse and practice. Anthropologia 47(2):215-232.

Nadasdy, P. 2007. The gift of the animal: the ontology of hunting and human-animal sociality. American Ethnologist 34 (1):25-43. http://dx.doi.org/10.1525/ae.2007.34.1.25

Natcher, D. C., O. Huntington, H. Huntington, F. S. Chapin III, S. F. Trainor, and L. DeWilde. 2007. Notions of time and sentience: methodological considerations for Arctic climate change research. Arctic Anthropology 44(2):113-126. http:// dx.doi.org/10.1353/arc.2011.0099

O'Flaherty, R. M., I. J. Davidson-Hunt, and M. Manseau. 2007. Keeping woodland caribou (ahtik) in the Whitefeather Forest. Sustainable Forest Management Network Research Note Series \#27. [online] URL: http://www.sfmn.ales.ualberta.ca/ en/Publications/ /media/sfmn/Publications/ResearchNotes/ Documents/E27 Caribou in the Whitefeather forest.ashx 
O'Flaherty, R. M., I. J. Davidson-Hunt, and M. Manseau. 2008. Indigenous knowledge and values in planning for sustainable forestry: Pikangikum First Nation and the Whitefeather Forest Initiative. Ecology and Society 13(1): 6. [online] URL: http:// www.ecologyandsociety.org/vol13/iss1/art6/

O'Flaherty, R. M., I. J. Davidson-Hunt, and A. M. Miller. 2009. Anishinaabe forest management values for the Whitefeather Forest, Pikangikum First Nation, Ontario: an ethno-ecological perspective. Pages 19-34 in M. G. Stevenson and D. Natcher, editors. Changing the culture of forestry in Canada: building effective institutions for Aboriginal engagement in sustainable forest management. Canadian Circumpolar Institute Press, Edmonton, Alberta, Canada.

Overholt, T. W., and J. B. Callicott. 1982. Clothed-in-fur, and other tales: an introduction to an Ojibwa world view. University Press of America, Washington, D.C., USA.

Pikangikum First Nation and Ontario Ministry of Natural Resources (OMNR). 2006. Keeping the land: a land use strategy for the Whitefeather Forest and adjacent areas. OMNR, Red Lake, Ontario, Canada. [online] URL: http:// www.whitefeatherforest.com/wp-content/uploads/2008/08/landuse-strategy.pdf

Rowe, J. S., and G. W. Scotter. 1973. Fire in the boreal forest. Quaternary Research 3:444-464. http://dx.doi.org/10.1016/0033-5894 (73) $90008-2$

Shearer, J., P. Peters, and I. J. Davidson-Hunt. 2009. Coproducing a Whitefeather Forest cultural landscape monitoring framework. Pages 63-84 in M. G. Stevenson and D. C. Natcher, editors. Changing the culture of forestry in Canada: building effective institutions for Aboriginal engagement in sustainable forest management. Canadian Circumpolar Institute Press, Edmonton, Alberta, Canada.

Spak, S. 2005. The position of indigenous knowledge in Canadian co-management organizations. Anthropologia 47 (2):233-246.

Surrallés, A., and P. Garcia Hierro, editors. 2005. The land within: indigenous territories and the perception of the environment. International Work Group for Indigenous Affairs, Copenhagen, Denmark.

Walker, B., S. Carpenter, J. Anderies, N. Abel, G. Cumming, M. Janssen, L. Lebel, J. Norberg, G. D. Peterson, and R. Pritchard. 2002. Resilience management in social-ecological systems: a working hypothesis for a participatory approach. Conservation Ecology 6(1): 14. [online] URL: http://www. consecol.org/vol6/iss 1/art14
Weir, J. M. H., E. A. Johnson, and K. Miyanishi. 2000. Fire frequency and the spatial age mosaic of the mixed-wood boreal forest in western Canada. Ecological Applications 10:1162-1177. http://dx.doi.org/10.1890/1051-0761(2000) 010[1162:FFATSA]2.0.CO;2

Westley, F., S. R. Carpenter, W. A. Brock, C. S. Holling, and L. H. Gunderson. 2002. Why systems of people are not just social and ecological systems. Pages 103-120 in L. H. Gunderson and C. S. Holling, editors. Panarchy: understanding transformations in human and natural systems. Island Press, Washington, D.C., USA.

Whitefeather Forest Initiative. 2004. Whitefeather Forest Research Cooperative Agreement. Whitefeather Forest Initiative, Pikangikum, Ontario, Canada. [online] URL: http:// www.whitefeatherforest.com/wp-content/uploads/2008/08/ wfrc agreement.pdf

Young, R. M. 1990. The mind-body problem. Pages 702-711 in R. C. Olby, G. N. Cantor, J. R. R. Christie, and M. J. S. Hodge, editors. Companion to the history of modern science. Routledge, London, UK. 